\title{
Tinospora merrilliana (Menispermaceae): an addition to the flora of India
}

\author{
Mishra S. ${ }^{1 *}$, Khristi S.M. ${ }^{2} \&$ S. Ray ${ }^{3}$ \\ ${ }^{1}$ Department of Botany, S.N. Govt. P.G. College, Khandwa Madhya Pradesh - 450 001, India \\ 2Department of Genetics, Ashok \& Rita Patel Institute of Integrated Study \& \\ Research in Biotechnology and Allied Sciences, New V.V. Nagar, Anand, Gujarat - 388 121, India \\ ${ }^{3}$ Department of Botany, P.M.B. Gujarati Science College, Indore, Madhya Pradesh - 452 001, India \\ ${ }^{\star}$ E-mail: dr.shakunmishra2012@gmail.com
}

\begin{abstract}
Tinospora merrilliana Diels, a little known endemic species of Central Malesia, is reported for the first time as a new record to the flora of India. The species was collected from the Telyababa forest range, Burhanpur district, Madhya Pradesh. A detailed description, distribution, habitat, colour plates, and a key to the species of Tinospora Miers in India are provided for easy identification.
\end{abstract}

Keywords: Central India, Menispermaceae, New record, Telyababa forest range, Tinospora.

\section{Introduction}

Tinospora Miers is a widespread genus in the family Menispermaceae comprising about 35 species and is distributed throughout tropical Africa, Madagascar, Asia to Australia and the Pacific Islands (Forman, 1981; Kessler, 1993; Pramanik \& Gangopadhyay, 1993; Udayan et al., 2009; Mujaffar et al., 2014; Rajendran et al., 2016; Wang et al., 2017; Mabberley, 2017; Lian et al., 2019; Mishra, 2020a,b; Mishra \& Mishra, 2020; Mishra et al., 2020a,b). The genus is represented by eleven species in India viz., T. baenzigeri Forman, T. cordifolia (Willd.) Miers ex Hook.f. \& Thomson, T. crispa (L.) Hook.f. \& Thomson, T. formanii Udayan \& Pradeep, T. glabra (Burm.f.) Merr., T. mahajanii Shakun Mishra, Khristi \& Solanki, T. maqsoodiana Mujaffar, Moinudd. \& Mustakim, T. neocaledonica Forman, T. sinensis (Lour.) Merr., T. smilacina Benth., and

Received: 21.07.2020; Revised \& Accepted: 18.01.2021

Published Online: 30.06 .2021
T. subcordata (Miq.) Diels (Mishra et al., 2020a). During our field studies in the period 2016-2018 in the Telyababa forest range in Madhya Pradesh, specimens of Tinospora were collected, which on further scrutiny were identified as $T$. merrilliana Diels, a species so far only known from Borneo, Philippines and Sulawesi. Hence, it is reported here as a new addition to the flora of India.

\section{Materials and Methods}

Morphological descriptions and ecological information presented here are based on field observations and material collected during fieldwork in the Telyababa forest range in the period 20162018. Detailed examination of the materials was done under an RXLr-5 stereo microscope (Radical Scientific Equipments, Ambala, India) and their identity was confirmed by comparison with the pertinent literature (Forman, 1981; Kessler, 1993; Pramanik \& Gangopadhyay, 1993; Xianrui et al., 2008; Udayan et al., 2009; Mabberley, 2017). Living plants of T. merrilliana were introduced to the botanical garden of the Department of Botany, Shri Neelkantheshwar Government Post Graduate College, Khandwa and voucher specimens were deposited at CAL and BSI.

\section{Taxonomic Treatment}

Tinospora merrilliana Diels, Pflanzenr. (Engler) Menispermac. 137. 1910; Elmer, Leaflets. Philipp. Bot. 4: 1164. 1911; Merrill, Enum. Philipp. Fl. P1. 2: 146. 1923. Fawcettia merrilliana (Diels) Yamam, 
Trans. Nat. Hist. Soc. Formosa 34: 230. 1944. Type: Sarawak, Haviland 1581 pro parte quoad inflor. masc (K [K000644577 digital image!]).

T. negrotica Diels, Pflanzenr. (Engler) Menispermac. 137. 1910. Type: PHILIPPINES, Negros, Elmer 9468 (holo B [B100294281 digital image!]).

Figs. 1 \& 2

Slender, woody, dioecious climber with slimy watery sap when cut; bark rough, drying striate. Stems up to $1 \mathrm{~cm}$ in diam., young stems $1.5-3 \mathrm{~mm}$ in diam., puberulous or glabrous; older stems covered with raised corky lenticels. Leaves with petioles 4-9 cm long, puberulous or glabrous, geniculate and slightly swollen at base; lamina narrowly ovate to ovate or broadly ovate, base truncate to deeply cordate, apex acuminate, 7-22 $\times$ 3-16 cm, palmately 5-7-nerved at base, main nerves usually impressed on upper surface and prominent below, both surfaces glabrous, texture stiffly chartaceous, domatia absent. Male inflorescences axillary or arising from older, leafless stems, pseudo-paniculate, 6-16 cm long, solitary or several branches arising together, very slender, puberulous, mostly without flowers in lower half of each branches. Male flowers on 2-5 mm long pedicels; sepals pale green, very thin, glabrous or sparsely puberulous, outer 3 ovate, 1-1.5 mm long, inner 3 obovate to spathulate, $2-3 \mathrm{~mm}$ long; petals 6 , unguiculate with distinct oblate limb, 1.5-2 mm long, apically fleshy; stamens 6 , narrowly clavate, 2-2.5 mm long. Female inflorescences bracteate, pseudo-racemose, solitary, $15-30 \mathrm{~cm}$ long, very slender, puberulous. Female flowers on 4-7 mm long pedicles; sepals and petals same as in males; staminodes absent; carpels 3, ellipsoid, 1.5-2 mm long; style terminal; stigma very strongly lobed. Infructescences narrowly pseudo-paniculate, up to $30 \mathrm{~cm}$ long, pendent with slender peduncle up to $23 \mathrm{~cm}$ long, puberulous. Drupes greenish at immature stage, greenish-white when ripe, radiating from sub-globose carpophore 1-2 mm in diam. on peduncles, 4-6 $\mathrm{mm}$ long; pericarp glabrous, drying close to endocarp, mesocarp pulpy, endocarp thinly crustaceous, usually pale, broadly ellipsoidal, 7-8 $\mathrm{mm}$ long, dorsally with an obscure medium ridge, surface smooth or obscurely tuberculate, ventrally flattish with elliptic aperture leading to deeply intrusive condyle.

Flowering \& fruiting: Flowering from October to December and fruiting from January to May.

Habitat: This species grows in loamy soil along with hedges around cultivated field at an altitude of 318 $\mathrm{m}$. It is rare and sparsely distributed occurring sympatrically with Tinospora sinensis. The associated plants in the locality are Clerodendrum phlomidis L.f. (Lamiaceae), Ailanthus excelsus Roxb. (Simaroubaceae) and Azadirachta indica Juss. (Meliaceae).

Distribution: Southeast Asia to South Asia from Borneo, Philippines Sulawesi and now in India.

Specimen examined: INDIA, Madhya Pradesh, Burhanpur district, Telyababa forest range, 20.02.2019, Shakun Mishra 1019 (BSI, CAL).

Notes: Tinospora merrilliana is a little known endemic species of Central Malesia, disjunctly distributed in some parts of Asia-tropical including Borneo, Philippines (Palawan, Luzon, Catanduanes, Panay, Mindanao) and Northeast Sulawesi (Minahassa). It is morphologically closely allied to Tinospora dissitiflora (K.Schum \& Lauterb.) Diels but differs in many characters: the petioles in T. merrilliana are geniculate basally and slightly swollen whereas it is not geniculate in $T$. dissitiflora. In addition, only the latter species has glandular patches in basal nerve axils. Further, the inflorescences of the two species are different. T. merrilliana shows bracteate, pseudoracemose, solitary female inflorescence; $15-30 \mathrm{~cm}$ long puberulous peduncles; female flowers on 4-7 mm long pedicles; absence of staminodes and, three carpels towards the periphery whereas in $T$. dissitiflora shows male axillary inflorescences or arise from older, leafless stems, pseudopaniculate; female inflorescences pseudopaniculate towards the base; male flowers on very slender pedicels, 5-10 mm long; female flower with 6 staminodes and subulate. Similarly, the drupes of T. merrilliana are 


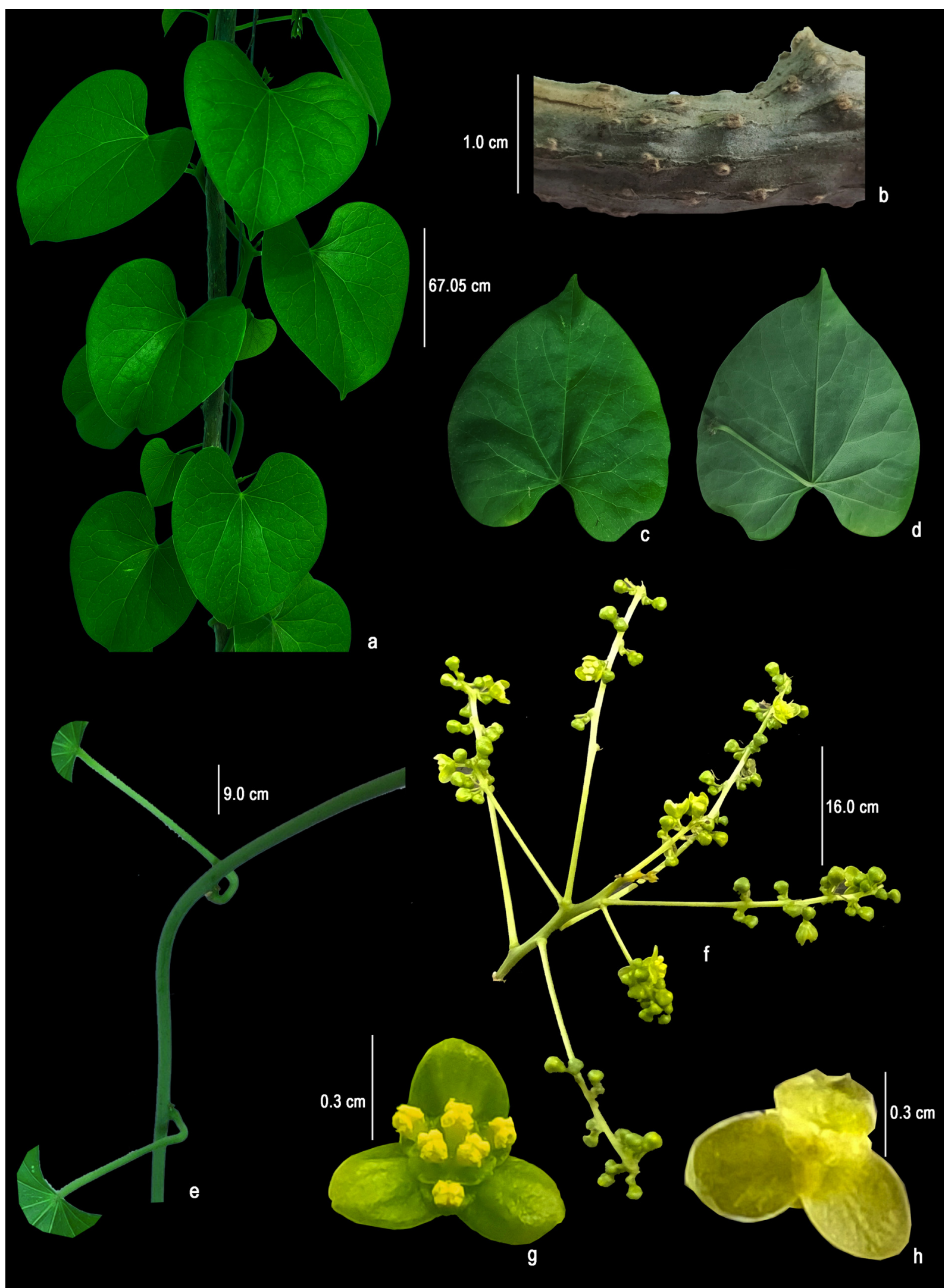

Fig. 1. Tinospora merrilliana Diels: a. Twig; b. Woody stem with raised corky lenticels; c. Adaxial view of leaf; d. Abaxial view of leaf; e. Part showing geniculate and slightly swollen petiole base; f. Male inflorescence; $\mathbf{g}$. Male flower-front view; h. Male flower-back view (from Mishra 1019; photos by D. Mishra). 


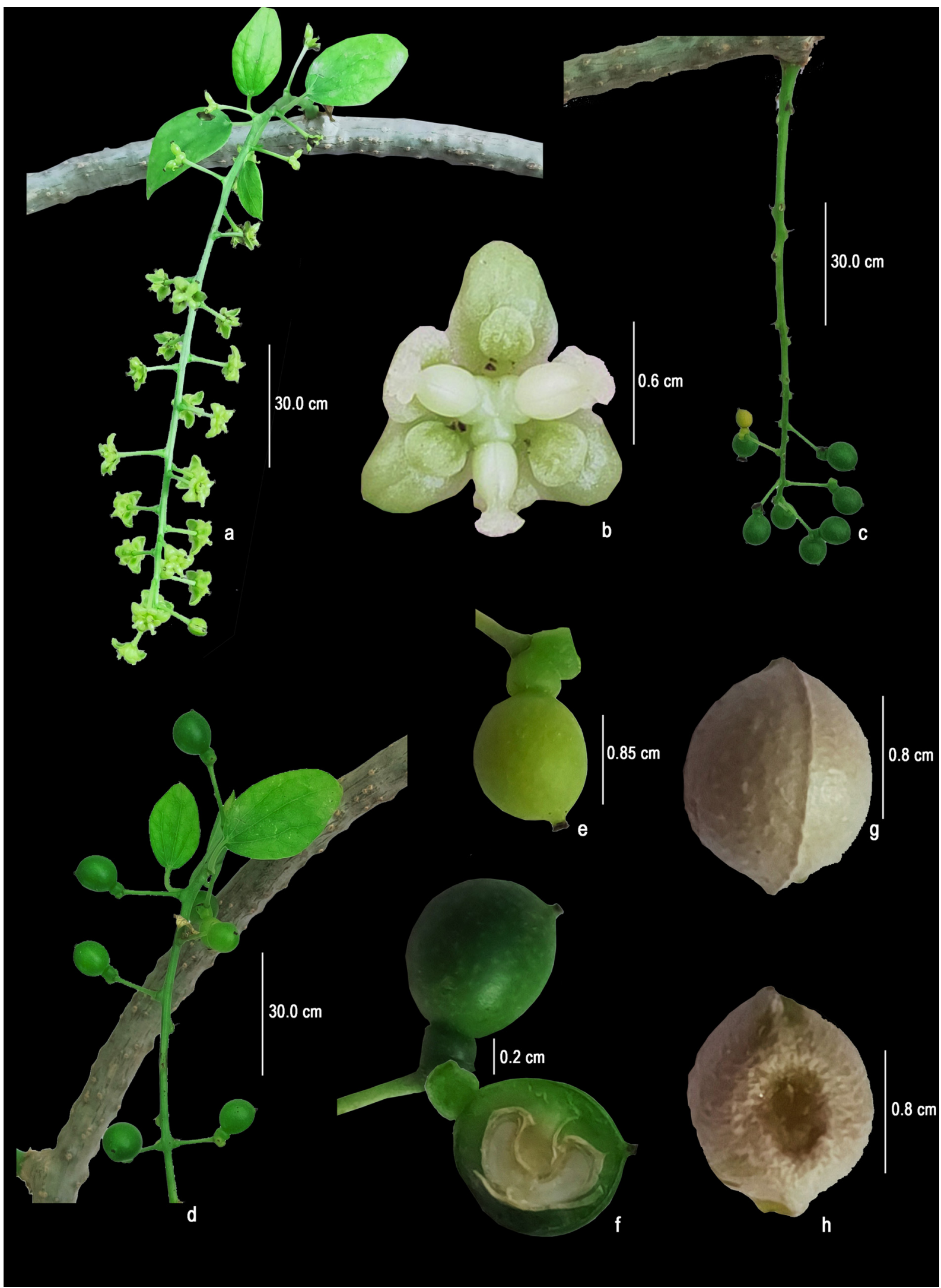

Fig. 2. Tinospora merrilliana Diels: a. Female inflorescence; b. Female flower-front view; c. Infructescence; d. Infructescence with leafy bracts; e. Mature drupe; f. Immature drupe with carpophore and longitudinal section of drupe; g. Endocarp-dorsal view; h. Endocarp-ventral view (from Mishra 1019; photos by D. Mishra). 
greenish when young and or later become greenish white, but in $T$. dissitiflora they are red. Moreover, the endocarp of T. merrilliana is broadly ellipsoidal in outline, 7-8 mm long, dorsally with an obscure medium ridge, smoother surface obscurely tuberculate. Whereas in $T$. dissitiflora the endocarp is bony, strongly and irregularly tuberculate, rather oblong in outline with squarish corners, 10-12 $\times$ 7-8 mm. Forman (1981) in his revision of the genus in Asia to Australia and the Pacific has not given details of the female inflorescence, which are provided here.

\section{Key to the species of Tinospora in India}

1. Climbers with very long filiform aerial roots

1. Climbers without or with short aerial roots 6

2. Leaves broadly sinuate T. sinensis

2. Leaves triangular 3

3. Stems strongly tuberculate; petals usually 3 ... T. crispa

3. Stems not tuberculate; petals usually 6 4

4. Leaves with a pair of hollow domatia in abaxial axils of basal veins T. baenzigeri

4. Leaves with glandular-papillose patches in abaxial axils of basal veins .... 5

5. Leaves with petioles $2-7 \mathrm{~cm}$ long T. cordifolia

5. Leaves with petioles $7-11 \mathrm{~cm}$ long T. maqsoodiana

6. Inflorescences branched . .7

6. Inflorescences unbranched 8

7. Infructescences up to $14 \mathrm{~cm}$ long T. mahajanii

7. Infructescences $15-30 \mathrm{~cm}$ long

T. merrilliana

8. Outer and inner sepals equal T. formanii

8. Outer sepals much smaller than inner sepals ..9
9. Leaves with domatia present on abaxial side in axils of basal nerve T. glabra

9. Leaves with glandular patches present on abaxial side in basal nerve axils 10

10. Leaves \pm ovate with sides convexly curved T. neocaledonica

10. Leaves \pm triangular to broadly triangular with sides straight or sometimes concave 11

11. Drupes borne on columnar carpophore, 4-5 $\mathrm{mm}$ long T. subcordata

11. Drupes borne on sub-globose carpophore, 1.5-2 $\mathrm{mm}$ long T. smilacina

\section{Acknowledgements}

The authors would like to express gratitude to the Curators of $\mathrm{K}$ and BGBM for providing online digital images and the University Grants Commission, Central Regional Office, Bhopal (Madhya Pradesh). The first author is also grateful to her supervisors Dr. C.M. Solanki and Dr. S.K. Mahajan for encouragements; to Dr. Mukesh Jain, Principal S.N. Govt. P.G. College, Khandwa and C.V.M. University, Vallabh Vidyanagar, Anand for facilities; Dr. Chandramohan K. (Assistant Conservator of Forest, Forest Survey of India) for their constant support and guidance; Arch. Devesh Mishra for photographs and for preparing the plates, and the anonymous reviewers for their critical comments that have helped to improve the quality of the manuscript.

\section{Literature Cited}

FORMAN L.L. 1981. A revision of Tinospora (Menispermaceae) in Asia to Australia and the Pacific: the Menispermaceae of Malesia and adjacent areas: X. Kew Bulletin 36(2): 375-421. https://doi.org/10.2307/ 4113613

KESSLER P.J.A. 1993. Menispermaceae. In: KUBITZKI K., ROHWER J.G \& V. BITTRICH (eds.), Flowering plants. Dicotyledons. The families and genera of vascular plants. Volume 2. Springer, Berlin. pp. 402-418.

LIAN L., ORTIZ R.D.C., JABBOUR F., CHEN Z.D. \& W. WANG 2019. Re-delimitation of Tinospora 
(Menispermaceae): implications for character evolution and historical biogeography. Taxon 68(5): 905-917. https://doi.org/10.1002/tax.12126

MABBERLEY D.J. 2017. Mabberley's Plants-Book: a portable dictionary of plants, their classification and uses. Fourth edition, Cambridge University Press, Cambridge.

MISHRA S. 2020a. Occurrence of a "New Caledonian" species Tinospora neocaledonica Forman (Menispermaceae) in India. Bioscience Discovery 11(2): 95-99.

MISHRA S. 2020b. Tinospora smilacina (Menispermaceae): a new distributional record for Flora of Central India, from (Khandwa district), India. Research \& Reviews: Journal of Botany 9(3): 17-20.

MISHRA S. \& D. MISHRA 2020. Occurrence of Tinospora subcordata (Menispermaceae): a new record to flora of India, from Khandwa district, Madhya Pradesh, India. Bioscience Discovery 11(2): 85-89.

MISHRA S., KHRISTI S.M. \& C.M. SOLANKI 2020a. Tinospora mahajanii (Menispermaceae), a new species from Khandwa district, Madhya Pradesh, India. Rheedea 30(4): 450-455. https://dx.doi.org/10.22244/ rheedea.2020.30.04.04

MISHRA S., ROY S. \& D. MISHRA 2020b. Tinospora baenzigeri (Menispermaceae): a new distribution record for the flora of India, from Burhanpur district, Madhya Pradesh, India. Bioscience Discovery 11(3): 137-141.

MUJAFFAR S., MOINUDDIN S. \& S. MUSTAKIM 2014.
Tinospora maqsoodiana (Menispermaceae), a new species from Madhya Pradesh, India. Indian Forester 140(5): 528-530.

PRAMANIK A. \& M. GANGOPADHYAY 1993. Menispermaceae. In: SHARMA B.D., BALAKRISHNAN N.P., RAO R.R. \& P.K. HAJRA (eds.), Flora of India. Volume 1. Botanical Survey of India, Kolkata. pp. 308-350.

RAJENDRAN A., PARTHIPAN M. \& A. SARVALINGAM 2016. Occurrence of an Australian species Tinospora smilacina Benth. (Menispermaceae) in India. Research E Reviews: Journal of Botany 5(1): 16-18.

UDAYAN P.S., PRADEEP A.K. \& I. BALACHANDRAN 2009. A new species of Tinospora (Menispermaceae) from South India. Edinburgh Journal of Botany 66(1): 7780. https://doi.org/10.1017/S0960428609005204

WANG W., ORTIZ R.D.C., JACQUES F.M.B., CHUNG S.W., LIU Y., XIANG X.G. \& Z.D. CHEN 2017. New insights into the phylogeny of Burasaieae (Menispermaceae) with the recognition of a new genus and emphasis on the southern Taiwanese and mainland Chinese disjunction. Molecular Phylogenetics and Evolution 109: 11-20. https://doi.org/10.1016/ j.ympev.2016.12.038

XIANRUI L., TAO C. \& M.G. GILBERT 2008. Menispermaceae. In: WU Z.Y., RAVEN P.H. \& D.Y. HONG. (eds.), Flora of China (Menispermaceae through Capparaceae). Volume 7. Science Press, Beijing \& Missouri Botanical Garden Press, St. Louis. pp. 1-31. 